\title{
Okul Öncesi Öğretmenlerinin Dış Mekân Oyunlarına Karşı Bakış Açılarının İncelenmesi*
}

\section{Investigation of Early Childhood Educators' Perspectives Towards Outdoor Play}

\author{
Hatice Şebnem ÇETKEN**
}

\section{Serap SEVIMLI-ÇELIK ${ }^{* * *}$}

Received: 16 January 2018

Accepted: 03 March 2018

\begin{abstract}
In this study, early childhood educators' attitudes, implementations and experiences towards outdoor play were investigated during May and June of 2015-2016 academic year. 30 early childhood educators from six private schools in Çankaya, Ankara got involved to the study. Open-ended questionnaire which developed by researchers is used for the research. This questionnaire consists of two parts. First part includes demographical information about educators and second part includes questions about attitudes, level of knowledge and competence. Results show that early childhood educators generally aware of the importance of the outdoor play. On the other hand, due to the intensive educational programs, weather conditions and limited outdoor play environment, children cannot get chance to play in the outdoor area. With the results of the study, early childhood education programs can be arranged according to child-centered and active learning perspectives. This study can provide basis to develop active learning environment by doing, experiencing, questioning and solving the problems with emphasizing importance of outdoor play.
\end{abstract}

Keywords: outdoor play, outdoor play areas, early childhood education, early childhood educators.

ÖZ: Bu çalışma ile okul öncesi öğretmenlerinin dış mekân oyunlarına karşı tutumları, uygulamaları ve deneyimleri incelenmiştir. Çalışma 2015-2016 akademik yılının Mayıs ve Haziran aylarını kapsayan süre içerisinde gerçekleştirilmiştir. Ankara Çankaya ilçesinde bulanan altı özel okul öncesi kurumdan 30 okul öncesi öğretmeni araştırmaya dâhil olmuştur. Araştırmacılar tarafindan geliştirilen açık uçlu sorulardan oluşan formunun ilk bölümünde katılımcıların demografik bilgileri ikinci bölümünde ise dış mekân oyunlarına karşı tutumları, bilgi düzeyleri ve yeterlilikleri sorulmuştur. Çalışmanın bulguları okul öncesi öğretmenlerinin dış mekân oyunlarının öneminin farkında olduklarını göstermiştir. Diğer bir taraftan yoğun eğitim programları, hava koşulları ve sınırlı dış mekân oyun alanları nedeniyle çocuklar dış mekân oyunları için firsat bulamamaktadır. Okul öncesi eğitim programları çocuk merkezli ve aktif öğrenmeyi destekleyecek şekilde düzenlenmelidir. Bu çalışma dış mekân oyunlarının okul öncesi eğitim programlarındaki önemi belirterek çocuklar için yaparak yaşayarak, sorgulayarak ve problem çözerek aktif öğrenme ortamının oluşturulmasına zemin hazırlamaktadır.

Anahtar Kelimeler: dış mekân oyunları, dış mekân oyun alanları, okul öncesi eğitim, okul öncesi öğretmenleri.

\footnotetext{
* A part of this work was presented as an oral presentation at 20th IPA Triennial World Conference in Calgary, Alberta in September 2017.

${ }^{* * *}$ Corresponding Author: Res. Asst., Usak University, Usak, Turkey, scetken@gmail.com

**** Asst. Prof. Dr., Middle East Technical University, Ankara, Turkey, serapsevimli@ gmail.com

\section{Citation Information}

Cetken, H. S., \& Sevimli-Celik, S. (2018). Okul öncesi öğretmenlerinin dış mekân oyunlarına karşı bakış açılarının incelenmesi. Kuramsal Eğitimbilim Dergisi [Journal of Theoretical Educational Science], 11(2), 318-341.
} 


\section{Giriş}

Oyun, yıllar boyunca birçok eğitimci ve filozof tarafından araştırılan ve alan yazında önemli bir yere sahip olan bir konudur. Bu sebeple farklı kaynaklarda ve sözlüklerde oyunun çeşitli teorileri ve tanımları bulunmaktadır. Oyun çocukların ihtiyaçlarına ve isteklerine göre kontrol edilen davranışlardır (Johnson, Christie \& Yawkey, 1998). Oyun çocuklar tarafından yönetilir, eğlencelidir ve kendiliğinden ortaya çıkar (Anderson-McNamee \& Bailey, 2010). Yetişkinlerin bakış açısından oyun, işlerini bitirdikten sonrası için bir rahatlama aracıdır. Diğer taraftan çocukların bakış açısından oyun yaşamaktır ve de yaşamak bir oyundur (Mayesky, 2009). Montessori'nin tanımladığı gibi oyun çocukların işidir (akt: Toksoy, 2010).

Araştırmalara göre oyun çocuğun gelişimine yardımcı olan önemli etkenlerden biridir (Anderson-McNamee \& Bailey, 2010; Clements \& Samara, 2009). Oyun ve çocukların gelişimi üç ayrı yönden ilişkilendirilebilir. İlk olarak, oyun çocukların gelişimlerini yansıtan bir ayna olarak görülebilir. İkincisi, oyun çocukların kendilerini ifade edebilmeleri ve gelişimsel kazanımlarının sağlamlaştırılması için ortam sağlar. Ayrıca oyun gelişimsel değişikler için bir araçtır. $\mathrm{Bu}$ nedenle oyun gelişimle sonuçlanabilir (Johnson, Christie \& Yawkey, 1998). Oyunun çocukların yaşamlarındaki önemi bilişsel, sosyal ve fiziksel gelişim alanları gibi farklı gelişimsel boyutları desteklemesiyle açıklanabilir. Oyun çocuğun sosyal, fiziksel ve bilişsel becerilerinin gelişmesine yardımcı olur (Anderson-McNamee \& Bailey, 2010). Oyunun çocuğun gelişim alanlarına olan katkısını kanıtlayan pek çok araştırma bulunmaktadır. Aşağıda oyunun her bir gelişim alanına olan etkisi özetlenmiştir.

\section{Oyun ve Bilişsel Gelişim}

Çocuklar başkalarıyla oyun oynayarak yeni kurallar, problem çözme yöntemleri ve farklı kavramlar öğrenirler (Anderson-McNamee \& Bailey, 2010). Oyun çocukların dünya hakkındaki görüşlerini test etmeleri için fırsat sunar. Mesela çocuklar günlük oyunları sırasında farklı matematiksel kavramları kullanırlar. Zengin ve destekleyici oyun deneyimleri çocukları ileriki matematik eğitimlerine hazırlar ve dünyayı yeni yollarla algılamalarını sağlar (Clements \& Samara, 2009).

Ayrıca oyun çocukların kendi hayal güçlerini geliştirirken yaratıcı olmalarına olanak sağlar. Oyun yardımıyla boyut, şekil ve doku kavramlarını öğrenirler (Ahern, Beach, Leibke, Proud, Spencer, \& Strickland, 2011; Anderson-McNamee \& Bailey, 2010).

Çocukların okuldaki başarıları, kullanılan öğretme metotlarıyla birlikte değişiklik gösterir. Eğer çocuk daha aktif olabileceği ve kendi deneyimleriyle öğrenebileceği bir eğitim ortamına sahipse, daha başarılı bir okul yaşamı olabilir. Bu sebeple oyun çocukların bilişsel gelişimleri için iyi bir yöntem olarak kullanılabilir (Marcon, 2002). Araştırmalar düşük düzeyde fiziksel aktivitelerin çocukların akademik başarısını olumsuz şekilde etkilediğini göstermektedir. $\mathrm{Bu}$ nedenlerle fiziksel aktivitelerin ve eğitimlerin çocukların aktif olabileceği şekilde zenginleştirilmesi gerekmektedir (Haapala, Poikkeus, Tompuri, Kukkonen-Harjula, Leppanen, Lindi \& Lakka, 2014). 


\section{Oyun ve Sosyal Gelişim}

Bilişsel gelişimin yanı sıra, oyun çocukların sosyal gelişimleri için de önemlidir. Çocukların oyun sırasında duygularını ifade edebilmeleri ve rahatlamaları okul başarılarını olumlu etkilediği düşünülmektedir. Aradaki bu pozitif ilişki oyunun okul öncesi eğitimde desteklenmesi gerektiğini kanıtlamaktadır (Zych, Ortega-Ruiz \& Sibaja, 2016). Oyunun çocukların becerilerini geliştirmesi için sunduğu fırsat aynı zamanda onların özgüvenlerini geliştirmelerine yardımcı olur. Oyun sırasında çocuklar kendi görüşlerini, deneyimlerini ve hayal kırıklıklarını ifade edebilirler. Ayrıca, başka çocuklarla birlikte oyun oynamak çocuklara bir grubun parçası olmayı öğretmeye yardımcı olur. Bu sayede paylaşmayı, uzlaşmayı, birlikte problem çözmeyi, adaleti ve grup olarak çalışmayı öğrenirler. Oyun çocukların kuralları ve toplum içinde nasıl hareket etmeleri gerektiğini öğrenmelerine yardımcı olur (Ahern \& diğerleri, 2011; Anderson-McNamee \& Bailey, 2010; Ginsburg, 2007).

Çocuklar oyun sayesinde iradelerini geliştirirler ve oyun esnasında başkalarıyla iletişim içinde olmaları bu açıdan önemli bir etkendir. Örneğin, çocuklar sosyo-dramatik oyun sırasında kendi oyunları için bir çerçeve oluştururlar ve bunun için başkalarıyla iş birliği yaparlar. Bu süreç içerisinde dili etkin olarak kullanmaları ve dil gelişiminin yanı sıra, oyunun sosyal gelişimlerine de faydalı olduğu görülür. Aynı zamanda bu durum çocukların öğrenme süreçlerine de katkıda bulunur (Weisberg, Zosh, Hirsh-Pasek \& Golinkoff, 2013).

\section{Oyun ve Fiziksel Gelişim}

Oyunun en belirgin faydalarından birisi fiziksel gelişime bulunduğu katkılardır. Özellikle günümüzde çocukların hareketsiz yaşamlarından kaynaklı oluşan obezite gibi sağlık problemleri, oyun yardımıyla fiziksel aktivite seviyesinin arttırılmasının etkisiyle azalma gösterebilir (Afsharlahoori, 2007; Ahern \& diğerleri, 2011; Ginsburg, 2007). Farklı oyun türleriyle birlikte çocukların ince ve kaba motor gelişimleri desteklenir (Anderson-McNamee \& Bailey, 2010). Örneğin, bloklar ve lego ile oynanan yap1 oyunları çocukları el-göz koordinasyonunu ve küçük kas gelişimini destekler. Denge tahtası, ip atlama ya da sek sek gibi oyunlar çocukların büyük kas gelişimlerine katk1 sağlar. Böylelikle fiziksel oyunlar sayesinde çocukların kasları güçlenir, çevikliği, denge ve dayanıklılıkları artar (Ahern ve diğerleri, 2011).

Fiziksel olarak belirli hareket ve güç gerektiren koşma, atlama ve tırmanma gibi hareketleri içeren oyunlar solunum, dolaşım, sindirim ve boşaltım gibi çeşitli vücut sistemlerinin düzenli bir şekilde çalışmasına yardımcı olur. Aynı zamanda özellikle büyümeyi sağlayan iç salgı bezleri bu tip hareketli oyunlar sayesinde daha düzenli çalışır ve çocukların fiziksel gelişimine katkı sağlar (Koçyiğit, Kök \& Tuğluk, 2007).

Fiziksel aktivite ve oyun çocukların motor koordinasyonlarını geliştirerek bilişsel gelişimlerinin de zenginleşmesine katkıda bulunan önemli etkinliklerdir. Bunun için dış mekân oyunları doğal alan sunması nedeniyle önemli bir destektir (Pesce, Masci, Marchetti, Vazou, Saakslahti \& Tomporowski, 2016). Dış mekânlar çocuklara daha geniş bir alan sundukları için onlara serbest hareket etme imkânı sunar. Bu sayede çocuklar dünyayı kendi başlarına keşfetme şansı elde edebilirler (Burriss \& Burriss, 2011; Mayrand \& Waters, 2015). İç mekânda yapamadıkları koşma, tırmanma, yuvarlanma ve zıplama gibi büyük hareketleri yapabilirler (Rivkin, 2000) ve bu büyük 
hareketler oksijen alımını, kan dolaşımını ve dokulara taşınan besin miktarını arttırır ve vücut sistemlerinin düzenli çalışmasını sağlar (Ünal, 2009).

Dış mekânlar çocukların gelişim alanlarını desteklemek için oldukça zengin kaynaklara sahiptir. Özellikle diş mekân aktiviteleri kilo kontrolünü korumak, kas gelişimini desteklemek ve fizyolojik sağlığ 1 sağlamak için önemlidir (Burriss \& Burriss, 2011). Aynı zamanda dış mekânlar görüş alanı, koku ve ses gibi birçok farklı uyaranı çocuklara zengin bir şekilde sunmasına karşın eğitim programlarında yeteri kadar yer almadığı gözlemlenmektedir (Ahern ve diğerleri, 2011).

\section{Geçmişten Bugüne Oyun}

Geçmişten günümüze oyun algısının değişmesiyle birlikte kullanılan oyun alanlarının ve oyun materyallerinin de değişiklik gösterdiği görülmektedir. Ülkemizde geçmiş yıllarda oynanan oyunlara bakıldığında daha çok evin dışında, bahçede, sokakta veya boş bir alanda oynandığı görülmüştür. Bununla birlikte bireysel oyunların değil, grup oyunlarının yoğunlukta olduğu da görülmüştür (Başal, 2007). Çocukların ve öğretmenlerin oyuna bakış açıları daha çok eğlendirici ve keyif verici aktiviteler olup mekânsal olarak özel bir tanımda bulunmamaktadırlar. Çocuklar genel olarak koşma, bisiklet sürme, sallanma gibi aktif olabilecekleri ya da oyuncak bebekler, arabalar ve çeşitli sanat aktiviteleri ile geçirdikleri zaman dilimini oyun olarak düşünmektedirler (Tuğrul, Metin-Aslan, Ertürk \& Özen-Altınkaynak, 2014).

Geçmişte oyunlarda kullanılan materyallerin ağaç dalları, kozalak, taş, tahta parçası, ceviz, su, toprak, çamur gibi doğal ortamlarda ve açık alanlarda kolayca bulunabilecek materyaller olduğu görülmektedir. Günümüzde ise çocuklar daha çok bireysel olarak yapboz, lego, bebek, robot ve bilgisayar oyunları oynadıkları ve dışarıda geçirdikleri zamanın azaldığı gözlemlenmektedir. Doğal nesnelerle yapılan oyuncaklar yerini fabrikasyon ürünlerine bırakmıştır (Ahiloğlu-Lindberg, 2012; Başal, 2007; AlMansour, Sevimli-Celik \& Johnson, 2016).

Yapılan araştırmalara göre anne-babalar daha çok fiziksel olarak aktif olabilecekleri dış mekân oyunları tercih ettikleri ancak günümüzde çocukların daha çok bilgisayar oyunlarını tercih ettikleri görülmüştür. Özellikle önceki iki kuşaktan farklı olarak çocuklar günümüzde bireysel oynayabilecekleri iç mekân oyunlarını tercih etmektedir (Tuğrul, Ertürk, Özen-Altınkaynak \& Güneş, 2014). Çocuklar okul dışındaki zamanlarını daha çok televizyon izleyerek ya da kendi odaları ve evin salonunda oyun oynayarak geçirmektedir (Erbay \& Saltal1, 2012; Singer, Singer, D'Agnostino \& DeLong. 2009). Güvenlik endişesi ve ailelerin çocuklarla birlikte oyun oynamak için fazla zamanlarının olmaması dış mekân oyunlarının en belirgin engelleri olarak gözükmektedir. Bunun yanında çocuklar artık dışarıda oynamayı değil içeride televizyon ya da bilgisayar karşısında vakit geçirmeyi tercih etmektedir (Clements, 2004). Ülkemizde de çocukların dışarıda oynayabileceği boş alanların ve parkların azlığı, trafik sorunu ve insanların birbirlerine olan güvenlerin azalması gibi yine güvenlikle ilgili olan endişeler (Başal, 2007; Cevher-Kalburan, 2014b), teknolojinin gelişmesiyle birlikte oyun kültüründe gözlenen değişim (Ahiloğlu-Lindberg, 2012) diş mekân oyunlarının azalmasının başlıca nedenlerindendir.

$\mathrm{Bu}$ bilgileri göz önünde bulundurarak okul öncesi eğitim kurumları çocuklara dış mekân oyun alanları ve firsatları sunma konusunda destekleyici olabilir ve çocuklara daha çok firsat sunabilir. Ancak kurumlarda eğitim genellikle iç mekânlarda sınırlı 
kalmakta ve dış mekânların sunduğu olanaklar eğitimciler tarafından kullanılmamaktadır. Okul düzenlemelerinde açık alanların düzenlenmesinin ihmal edilmiş olduğu, fiziksel koşulların oyun firsatları sunmakta yetersiz olduğu ve çocukların hareket dürtülerini güdüleyecek donanıma sahip olmadıkları görülmektedir (Baran, Yılmaz \& Yıldırım, 2007; Çelik, 2012). Aynı zamanda okul bahçelerinde bulunan oyun alanları da geleneksel bir tasarımda olup çeşitli oyun firsatları sunma konusunda sinırlı kalmaktadır (Atabey, Yurt \& Ömeroğlu, 2009; Olgan \& Öztürk, 2011). Oyun alanları çoğunlukla sabit oyun ekipmanlarına sahipken doğal unsurları yeteri kadar içermemekte ve fiziksel büyüklük olarak yetersiz kalmaktadır (CevherKalburan, 2014a). Okul bahçelerinde doğal unsurlara yeterince verilmemektedir. Ancak çocuklar okul bahçelerinin ferah ve çeşitli bitki örtüsüne sahip olmasını tercih etmektedir. Alanın kalabalık ve yetersiz olması çocukların aktiviteleri için sınırlar oluşturmaktadır (Özdemir \& Yılmaz, 2008).

Johnson, Christie ve Yawkey'e göre (1998), okul öncesi eğitim kurumlarındaki dış mekân oyun alanlarının yanı sıra öğretmenlerin tutum ve davranışları da çocukların oyunlarına pozitif ya da negatif etki edebilir. Bu nedenle öğretmenlerin oyun sırasında üstlendikleri rolleri altı başlıkta toplanmış ve tanımlanmıştır. $\mathrm{Bu}$ roller katılımcı olmayan, gözlemci, ortamı sağlayan, katılımc1, yol gösterici ve güvenliği sağlayan olarak listelenmiştir.

Katılımcı olmayan öğretmen rolü kesinlikle çocukların oyunlarına aldırış etmez. Diğer taraftan gözlemci rolünü üstlenen öğretmenler oyuna müdahale etmeden ve devam eden aktiviteleri bölmeden genellikle çocukların oyunlarını izlerler. Çocuklarla gerekli bir durum olmadıkça iletişim kurmazlar ve onları rahatsız etmezler. Güvenliği sağlayan öğretmen rolü ise genel olarak çocukların oyunları sırasında dikkatli davranarak çocukların oyunlarının kurallara uygun olarak oynanmasını sağlar ve onların güvenli bir şekilde oyunu sürdürmelerine gerekli noktalarda müdahale ederek yardımcı olur.

Dış mekân oyunlarında yol gösterici öğretmen rolü çocukların oyunları sırasında onlara iyi bir rehber olarak ve onlara doğru cevaplar vererek iyi bir kaynak olan öğretmen rolüdür. Aynı zamanda çocukların oyun sırasında yaratıcılıklarını, problem çözme becerilerini, iletişimlerini destekleyerek onlara model olurlar. Ortam sağlayan öğretmen rolü öncelikle oyun için mekânı ve materyali sağladıktan sonra oyuna katılan grubu bir arada tutmaya, bütün çocukları oyuna dâhil etmeye ve öğrenciler arasındaki ilişkiyi ve dengeyi kurmaya yardımcı olur. Son olarak katılımcı öğretmen rolü dış mekân oyunlarına en yüksek katılımı sağlayan öğretmen rolüdür. $\mathrm{Bu}$ roldeki öğretmenler çocukların oyunlarına aktif bir oyuncu olarak katılır ve bir nevi arkadaş rolünü üstlenirler. Bu roller arasında çocukların oyunlarını en çok destekleyenler gözlemci, ortamı sağlayan, katılımcı ve güvenliği sağlayan öğretmen rolleridir. (Johnson, Christie \& Yawkey, 1998).

Türkiye'de dış mekân oyun alanları ile yapılan çalışmalara bakıldığında dış mekân oyun alanlarının özellikleri, alanların kullanımı ve çocukların fiziksel aktivite seviyesine etkisinin incelendiği çalışmalara rastlanmaktadır. Atabey, Yurt ve Ömeroğlu (2009), özel ve resmi okul öncesi kurumların dış mekân oyun alanlarını 'Okul Öncesi Eğitim Kurumları Açık Hava Oyun Alanı Kontrol Listesi’ ile incelemişler ve alanların yeterliliklerini belirlemişlerdir. Çalışmanın sonuçlarına göre özellikle bitkilerin yaşam döngülerini ve doğal yaşam ortamında gözlemleme fırsatları sunabilecek alanların 
yetersiz olduğu belirlenmiştir. Ek olarak, alanlarda farklı yaş gruplarına yönelik materyal sunma, oyuncak yeterliliği, su ve kum oyun alanları, çeşitli yüksekliklerde alanlardan oluşma gibi çocuklara farklı oyun deneyimi kazandırabilecek başlıklarda da alanların yetersiz olduğu belirlenmiştir. Benzer şekilde Ankara'daki özel ve devlet okul öncesi kurumlarının oyun alanlarının incelenmesiyle yapılan bir çalışmada alanlarda çoğunlukla geleneksel oyun alanı ekipman ve materyallerine rastlanmıştır (Olgan \& Öztürk, 2011). Aynı zamanda alanların çocukların oyunlarını geliştirmek için yeterli olmadığı belirlenmiştir. Yine Ankara'da yapılan bir başka çalışmada özel okullardaki dış mekânlar ve çocukların fiziksel aktiviteleri arasındaki ilişkiye bakılmıştır. Çalışmanın sonuçları alanların ve çocukların aktivitelerinin incelenmesinin yanı sıra öğrencilerle, öğretmenlerle ve okul yöneticileri ile yapılan görüşmelerle elde edilmiştir. Okula yürüyerek gidip gelen ve okullarında daha geniş dış mekâna sahip olan aktif çocukların vücut kitle indeksinin daha düşük olduğu belirlenmiştir. Ayrıca çocukların ferah ve daha çok bitkiye sahip olan alanları tercih ederken temel endişenin kalabalık dış mekân alanlarının çocuklarını aktivitelerini sınırlandırması olduğu belirtilmiştir (Özdemir \& Yilmaz, 2008).

Çelik (2012), Kocaeli ili örneği olarak okul öncesi kurumlardaki açık alan kullanımını, kişi başına düşen alanı ve alandaki donanımsal özellikleri belirlemek amacıyla yaptığı çalışmada kurumlarda bulunan açık alanların etkin olarak kullanılmadığı belirtmektedir. Bunun yanı sıra çalışma, kurumlardaki açık alanların oyunun doğasına uygun olmadığını ve açık alan düzenlemesinin çoğunlukla ihmal edildiğini göstermektedir. Türkiye'de belediyelere ait çocuk oyun alanlarının biçimsel özelliklerinin incelendiği bir araştırmada ise alanların planlama ve tasarım ilkeleri göz önünde bulundurularak oluşturulduğu tespit edilirken oyun materyallerinin birbirine benzer ve yetersiz oldukları belirlenmiştir (Duman \& Koçak, 2013).

Cevher-Kalburan (2014a), yaptığı çalışmada resmi ve özel anaokulu bahçelerinin fiziksel özelliklerini, kullanım ve geliştirilmesine yönelik uygulamaları ve karşılaşılan problemlerin belirlenmesini amaçlamıştır. Elde edilen sonuçlara bakıldığında doğal unsurlara yeterince yer verilmediği, özel okullarda bahçe kullanımı ile ilgili daha çok müdürlerin belirlediği kuralların olduğu, okul bahçelerinin geliştirilmesi konularına çocukların yeterince dâhil edilmediği ve bahçenin öğretim ortamı olarak görüldüğü ancak uygulamalarda bilişsel gelişimin amaç edinilmediği belirlenmiştir. Tepebağ ve Aktaş-Arnas'ın 2017 yılında yayınlanan okul öncesi öğretmenlerin okul bahçelerini eğitsel amaçla kullanıma yönelik görüşlerinin incelendiği çalışmanın sonuçları benzerlik göstermektedir. Öğretmenlerin çocukları bahçeye çıkarmasının amacı onların oyun oynamasını ve enerji harcaması sağlamak olarak belirlenmiştir. Ayrıca öğretmenler bahçede daha çok yönlendirici rolleri üstlenirken malzeme seçimi ve yerleşimi ile ilgilenmektedir. Güvenlik sorunu ve olumsuz hava koşulları bahçeye çıkma süresini azaltan faktörler olarak belirlenmiştir.

Cevher-Kalburan ve Yurt (2011) tarafından 20 okul öncesi öğretmeni ile yapılan yarı-yapılandırılmış görüşme sonucunda öğretmenlerin daha çok diş mekân etkinlikleri için sıcak havaları tercih ettiklerini belirlemişlerdir. Aynı zamanda öğretmenler dış mekânı kullanma konusunda yetersiz fiziksel alan ve ailelerin endişeleri sebebiyle oyun alanlarını kullanma konusunda sorun yaşamaktadır. Cevher-Kalburan (2014b), dış mekân oyun firsatları ile ilgili ebeveyn görüşlerinin incelendiği çalışma ile ebeveynlerin olumsuz görüşlerini göstermektedir. Çalışmada çıkan sonuçlara göre ebeveynlerin 
olumsuz görüşleri ile ilgili trafik, kötü niyetli olabilecek yabancılar, çocukların kaçırılma ve yaralanma endişeleri gibi unsurlar ortaya çıkmıştır. $\mathrm{Bu}$ araştırmalara ek olarak, dış mekân ile ilgili ebeveyn görüşleri ve öğretmen görüşlerinin belirlenmesine yönelik yapılan çalışmada öğretmenlerin açık hava etkinliklerine karşı olumlu düşünceleri olsa da fiziksel şartların ve güvenlik tedbirlerinin yetersizliği, kalabalık sınıf mevcudu, çocukların hastalanabileceğine dair endişeler ve olumsuz veli tepkileri gibi sebeplerden dolayı programlarında açık hava etkinliklerine yer veremedikleri belirlenmiştir (Alat, Akgümüş \& Caval1, 2012).

Alan yazınında da görüldüğü gibi dış mekân oyunu, çocukların gelişim alanlarını desteklemekle kalmayıp, çocukların gün içinde aktif olmalarını sağlayarak onlara deneme yanılma, problem çözme ve derinlemesine araştırma gibi becerilerini geliştirmek için çeşitli firsatlar sunan önemli bir unsurdur. Bu yüzden, okul öncesi öğretmenlerinin dış mekân oyunları ile ilgili öğretmen tutumları, uygulamaları ve deneyimleri açısından derinlemesine incelenmesi okul öncesi eğitim programlarının düzenlenmesi ve öğretmen eğitimi programları açısından önemlidir. Ancak Türkiye'de yapılan çalışmalar göz önünde bulundurulduğunda çalışmaların diş mekân oyun alanlarının incelemesi konusunda yoğunlaştı̆̆1 öğretmen görüşlerinin ve uygulamalarının belirlenmesine yönelik çalışmaların alan yazında sınırlı olduğu görülmektedir. Bu çalışma, öğretmenlerin dış mekân oyunları ile ilgili bakış açıları ve uygulamalarını belirlemek, konu ile ilgili belirli sorunlarını tespit ederek çocuklara nitelikli uygulamalar sunmak açısından önemlidir. Bu nedenle, çalışma ile okul öncesi öğretmenlerinin dış mekân oyunlarına karşı tutumları, sınıf uygulamaları ve deneyimlerinin incelenmesi amaçlanmıştır. Bu amaç doğrultusunda aşağıdaki araştırma soruları belirlenmiştir.

1-Okul öncesi öğretmenlerinin dış mekân oyunlarına karşı bakış açısı nasıldır?

2-Okul öncesi öğretmenlerinin dış mekân oyunlarına karşı tutumları, sınıf uygulamaları ve deneyimleri nasıldır?

\section{Yöntem}

Bu çalışmada, araştırma yöntemi olarak açık uçlu sorulardan oluşan formun nitel bir araştırma yöntemi olarak kullanılmasıyla birlikte, katılımcıların dış mekân oyunlarına karşı bakış açılarının belirlenmesi amaçlanmıştır.

\section{Katılımcilar}

Araştırmaya Ankara ilinin Çankaya ilçesine bağlı altı farklı özel okulda çalışan 30 okul öncesi ögrretmeni katılmıştır. Bölgede bulunan okullardan 15 tanesi rastgele şekilde seçilmiş ve 8 okul araştırmaya katılmayı kabul etmiştir. Araştırmanın devamında 2 okul iç prensipleri nedeniyle araştırmaya devam etmemiş ve altı okulla araştırma tamamlanmıştır. 
Tablo 1

Araştırmaya Katılan Öğretmenlerin Yaş Aralıkları

\begin{tabular}{lcc}
\hline Yaş Aralı̆̆1 & $\mathrm{n}$ & $\%$ \\
\hline & & 10 \\
$18-25$ & 8 & 36.6 \\
$26-30$ & 11 & 10 \\
$31-35$ & 3 & 10 \\
$36-40$ & 3 & 10 \\
$41-50$ & 3 & 6.6 \\
$50+$ & 2 & 96.6 \\
Toplam & $29 *$ & 2 \\
\hline
\end{tabular}

*Katılımcılardan 1 kişi yaşını belirtmemiştir.

Tablo 2

Araştırmaya katılan öğretmenlerin eğitim durumları ve şu an çalıştıkları kurumdaki çalışma süreleri

\begin{tabular}{lcc}
\hline & $n$ & $\%$ \\
\hline Eğitim Durumu & 3 & 10 \\
Lise & 10 & 33.3 \\
Yüksekokul & 13 & 43.3 \\
Üniversite & 4 & 13.3 \\
$\quad$ Yüksek Lisans & & \\
\hline Çalışma süresi & 5 & 16.6 \\
1 yıldan az & 5 & 16.6 \\
$1-2 y l l$ & 10 & 33.3 \\
$2-3 y l l$ & 4 & 13.3 \\
$3-5 y l l$ & 3 & 10 \\
$5-10 y l l$ & 2 & 6.6 \\
$10-15 y l l$ & 30 & 100 \\
Toplam & & \\
\hline
\end{tabular}

\section{İşlem}

Verilerin toplanması. Nitel araştırma yöntemi araştırmacıya verileri gerçekçi ve bütüncül olarak analiz etmeyi sağlayarak deneyim ve bakış açısı kazandırır (Karataş, 2015). Bu nedenle araştırmada okul öncesi öğretmenlerinin dış mekân oyunlarına bakış açılarının gerçekçi ve bütüncül olarak ele alınması sebebiyle, nitel araştırma yöntemlerinden biri olan açık uçlu sorulardan oluşan form uygulanmıştır. Araştırma için Etik Kurulu Onayı alınmış ve okul öncesi öğretmenleri araştırmaya Gönüllü Katılım Formu dağıtılarak dâhil edilmiştir. Daha sonra okul öncesi öğretmenlerine ilk bölümde demografik bilgilerin sorulduğu ve ikinci bölümünde dış mekân oyunlarına karşı 
tutumlarının, bilgi düzeylerinin ve yeterlilik düzeylerinin sorulduğu açık uçlu sorulardan oluşan formlar dağıtılmıştır. 13 sorudan oluşan formun cevaplanma süresi yaklaşık 3045 dk.'dır. Sorular öğretmenlere yazılı olarak verilmiş ve cevaplar da aynı şekilde toplanmıştır. Açık uçlu sorulardan oluşan bu form araştırmacılar tarafından hazırlanmış olup bir uzmandan görüş alınmıştır. Alınan görüş doğrultusunda formun iki sorusunda değişiklik yapılmıştır. Değişiklik yapılan sorular aşağıda verilmiştir.

'Dış mekân (açık hava) oyunları sırasında çocukların oyunlarına katılım düzeyiniz nedir? Her bir madde için ne tür bir katılım yaptığınızı kısaca anlatabilir misiniz?' sorusunda bahsedilen maddeler hiç katılmıyorum, kısmen katılıyorum ve tamamen katılıyorum şeklinde sunulmaktadır. Uzman görüş sonrasında seçeneklerin başına 'oyuna' kelimesi eklenerek oyuna hiç katılmıyorum, oyuna kısmen katılıyorum ve oyuna tamamen katılıyorum olarak değiştirilerek daha anlaşılır olması amaçlanmıştır. Ayrıca katılımcıya fikir verebilmesi için 'örneğin, sadece izliyorum, gerektiğinde müdahale ediyorum, oyun oynuyorum, oyun kuruyorum’ kısmı sorunun son kısmına eklenmiştir.

'Dış mekân (açık hava) oyunları için belirtilen zaman dilimi mevsimsel (yaz/kış/bahar) olarak farklılık gösteriyor mu?' sorusunda evet seçeneğini işaretleyenler için sorunun alt kısmına 'nedenlerini belirtiniz' maddesi eklenerek cevapların ayrıntılı bir şekilde alınabilmesine olanak sağlanmıştır.

Verilerin analizi. Açık uçlu sorularla verilerin elde edildiği nitel araştırmaların değerlendirilmesinde kullanılan yöntemlerden birisi içerik analizidir (Yıldırım \& Şimşek, 2011). Bu çalışmada da formda yer alan sorularla birlikte ortaya çıkan dış mekân kavramı, öğretmen rolleri, dış mekân oyunları ve materyalleri, okullarda bulunan ekipmanlar ve çocukların dış mekân oyun tercihleri başlıkları içerik analizi yöntemiyle incelenerek ilk olarak kodlar belirlenmiştir. Kodların altında kümelenen veriler sınıflandırılarak temalar oluşturulmuştur. Kodlayıcılar tarafından aynı veri seti üzerinde yapılan kodlamalar arasındaki tutarlık Miles-Huberman modeline göre hesaplanarak \%94 bulunmuş ve görüş birliği \%80 sınırını aştığı için güvenirlik sağlanmıştır (akt: Baltac1, 2017).

\section{Bulgular}

Araştırmanın bu bölümünde okul öncesi öğretmenlerinin dış mekân oyunları, öğretmen rolleri, uygulamaları ve materyalleri ile ilgili görüşlerinden elde edilen bulgulara yer verilmiştir. Katılımcıların görüşleri, gizlilik esasının sağlanabilmesi için isimleri verilmeden öğretmenleri temsil etmesi için "Ö" harfinin yanına 1 ile 30 arasından sayılar verilerek gösterilmiştir.

\section{Dış Mekân Oyunlarını İç Mekân Oyunlarından Ayıran Özellikleri ile İlgili Görüşler}

Dış mekân oyunları denildiğinde öğretmenlerin aklına gelenler ve dış mekân oyunlarını iç mekân oyunlarından ayıran özellikler sorulduğu zaman öğretmenlerin cevapları geniş mekân $(n=30)$, doğayı tanıma $(n=27)$, materyal çeşitliliği $(n=23)$, sağlıklı $(n=15)$ ve fiziksel gelişim $(n=15)$ kavramları üzerine yoğunlaşmıştır. Bununla birlikte öğretmenler $(n=26)$ dış mekânının iç mekâna göre tanıdığı daha geniş oyun alanının serbestlik ve özgürlük tanıdığını belirtmişlerdir. Doğayı tanıma ile ilgili olarak 
keşfetme ve araştırma ( $n=16)$ öne çıkan kavramlar olurken, doğa ile oyun yaratma ve doğa sevgisi sadece 1 katılımcı tarafından belirtilmiştir.

Ayrıca öğretmenler dış mekân ile ilgili olarak sosyal gelişim $(n=10)$ ve yaratıcılık ( $n=9)$, kavramlarından bahsederken genel başlıklar altında bilişsel gelişimden sadece 5 katılımcı bahsetmiştir. Bunlara ek olarak öğretmenler eğlence $(n=5)$, oyun $(n=5)$, duygusal gelişim $(n=2)$, ve çocukluk $(n=1)$ cevaplarını vermişlerdir.

'Dışarıda keşfedilecek kocaman bir hayat var. Doğa ile iç içe çocuklar. Çevresini hava değişimini ve canlıları tanıma firsatı sağlar.' (Ö10)

'Dış mekân oyunlarında alan geniş olduğu için oyun oynama daha zevkli ve ak1c1 oluyor.' (Ö27)

'Sınırsız gökyüzü (tavan kısıtlıyor), temiz hava'(Ö15)

\section{Dış Mekân Oyunlarının Gelişimsel Faydaları ile İlgili Görüşler}

Öğretmenler dış mekân oyunlarının gelişimsel faydalarını üç temel gelişim alanı (bilişsel, fiziksel ve sosyal-duygusal) altında başlıklarla belirtmişlerdir. Bilişsel gelişim alanı ile ilgili olarak en çok belirtilen hayal dünyası/yaratıcılık $(n=6)$, problem çözme becerisi $(n=6)$, konsantrasyon $(n=5)$ ve merak duygusu gelişimidir $(n=6)$. Bununla birlikte kavram öğrenme $(n=1)$, analiz etme $(n=1)$, neden-sonuç ilişkisi kurma $(n=2)$, beyin fırtınası $(n=2)$ ve mantık yürütme $(n=2)$ daha az belirtilen başlıklar arasındadır.

'Çocuklar açık havada oynadığında merak duygusu gelişir.' (Ö7)

'Dikkat becerisini geliştirir.' (Ö9)

'Daha aktif hayal güçleri olur. Problem çözme becerilerini geliştirir.' (Ö11)

Fiziksel gelişim ile ilgili öğretmenlerin en çok bahsettiği kavramlar enerji harcanması $(n=7)$, ince ve kaba motor gelişimi $(n=19)$, kas gelişimi $(n=6)$, bedeni ve vücudu tanımadır ( $n=4)$. Bunların yanı sıra duyu gelişimi $(n=2)$ ve alan farkındalığ $(n=3)$ daha az belirtilen kavramlar olurken denge ve ritim duygusunun gelişimi sadece bir öğretmen tarafından belirtilmiştir.

'Enerjilerini atarlar.' (Ö6)

'Alan farkındalığı, büyük kas gelişimi, denge.' (Ö25)

Genel olarak öğretmenlerin sosyal-duygusal gelişim ile ilgili vurguladığ başlıklar arkadaşlık $(n=8)$, grup ile hareket etme $(n=7)$ ve kendini ifade etme $(n=6)$ konusunda yoğunlaşmışken, paylaşmayı öğrenme $(n=5)$ özgüven kazanma $(n=5)$ ve kazanma-kaybetmeyi öğrenme $(n=5)$ öne çıkan diğer başlıklardır. Bunlara ek olarak öğretmenler diş mekân oyunlarının stresi azalttığını $(n=3)$, empati duygusunun $(n=3)$ ve iletişim becerilerinin gelişmesinden $(n=4)$ bahsetmişlerdir.

'Stres düzeyinin azalmasına yardımcı olur.' (Ö14)

'Paylaşmayı, sırasını beklemeyi, grupla hareket etmeyi öğrenir. Özgüveni artar.' (Ö10)

'Arkadaş ilişkileri noktasında daha olumlu süreçlerin oluşmasında etken olmaktadır.' (Ö22)

\section{Dış Mekân Oyunlarında Öğretmen Rolleri ve Oyuna Katılım Durumu}

Öğretmenlerin dış mekân oyunları sırasında üstlendikleri rollerin neler olduğunu sıralaması istenmiş ve verilen cevaplar Johnson, Christie ve Yawkey (1998)'in oyun 
sürecindeki öğretmen rollerinin açıklamaları doğrultusunda beş başlık altında toplanmıştır. Bu başlıklar gözlemci, güvenliği sağlayan, yol gösterici, ortamı sağlayan ve katılımcı olarak oyuna katılım derecelerine göre sıralanmaktadır. Öğretmenlerin verdikleri cevaplardan bazıları ve hangi başlık altına girdikleri örnek olarak gösterilmiştir.

'Kuralların neler olduğunu anlatmak, kurallara uyulmadığ 1 zaman neler olacağının bilmesi gerektiğini hatırlatmak.' - Güvenliği Sağlayan

'Öğretmen aktif bir gözlemci olmalı.' - Gözlemci

'Zaman zaman oyuna girerek çocuğun oyun arkadaşı olabilir.' - Katılımcı

'Oyun bahçesini hazırlamak ve oyunları kurmak.' - Ortam Sağlayan

'Oyunun doğasına göre çeşitli komutlar vermek.' - Yol Gösterici

Aşağıdaki tablo araştırmaya katılan öğretmenlerin üstlendikleri rollere göre düzenlenmiştir. Bazı öğretmenler aynı zamanda birden fazla rolü üstlendiklerini belirtmişler tabloda üstlenilen roller ona göre ayarlanmıştır.

Tablo 3

Öğretmenlerin Dış Mekân Oyunlarındaki Rol Süreci

\begin{tabular}{lc}
\hline Öğretmen Rolleri & $n$ \\
\hline Güvenliği Sağlayan & 24 \\
Yol Gösterici & 28 \\
Ortam Sağlayan & 29 \\
Katılımcl & 13 \\
Gözlemci & 16
\end{tabular}

Yukarıdaki öğretmen rolleri tablosunda da görüldügüü üzere öğretmenler diş mekân oyunları sırasında daha çok ortamı sağlayan ve yol gösterici rollerini üstlenirken katılımcı rolü daha az görülmektedir.

Tablo 4

Öğretmenlerin Dış Mekân Oyunlarına Katılım Durumu

\begin{tabular}{lcc}
\hline Oyuna Kat1lım Durumu & $\mathrm{n}$ & $\%$ \\
\hline Oyuna Katılmiyorum & 0 & 0 \\
Oyuna Kismen Katıliyorum & 21 & 70 \\
Oyuna Tamamen Kat1lyorum & 9 & 30 \\
Toplam & 30 & 100
\end{tabular}

Cevaplara paralel olarak oluşturulan ve öğretmenlerin çocukların dış mekân oyunları sırasında onların oyunlarına katılım durumlarını gösteren tablo 5'te de görüldüğü üzere öğretmenler çoğunlukla dış mekân oyunlarına kısmen katıldıklarını belirtiyorlar. Katılımcılar genellikle kuralları açıklamak için $(n=5)$ ya da sorun olduğu 
zaman ( $n=5)$ çocukların oyunlarına katıldıklarını belirtirken, öğrencilere özgürlük tanımak için $(n=5)$ oyunlara katılmadıklarını vurgulamışlardır.

'Çocukları gereksiz müdahale olmadan aktivitelerinde ve seçimlerinde özgür olabilmeleri için desteklemeliyim.’ (Ö27)

'Duruma, oyuna, hava koşullarına ya da çocuğa bağlı olarak oyununa en az müdahaleyi yapmaya çalışırım.' (Ö8)

'Özellikle eski geleneksel oyunları öğretmek için ilk başta oyuna dâhil olarak kuralları anlatıyorum. Oyunu birkaç sefer oynadıktan sonra yorulduğumu söyleyerek çekiliyorum.' (Ö4)

Oyuna tamamen katıldığını söyleyen öğretmenler oyuna liderlik ettiklerini $(n=6)$, oyuna katılmayı sevdiklerini ve çocuklarla birlikte oynamaktan keyif aldıklarını $(n=3)$ belirtmiştir. Aynı zamanda çocukların da onları oyunlarında katılımcı olarak görmek istediklerini ve bu yüzden dış mekân oyunlarına katıldıklarını vurguladılar. Araştırmanın verilerine göre dış mekân oyunlarına katılmıyorum seçeneğini işaretleyen öğretmen bulunmamakla birlikte sonuçta öğretmenlerin çocukların diş mekân oyunlarına kısmen katılımının yoğunlukta olduğunu belirleyebiliyoruz.

'Çocuklarla futbol maçına katılıyorum. Bu çocukların enerji ve motivasyonunu fazlasıyla arttırıyor. Özellikle de kız çocuklarına modelleme imkânına sahip oluyorum.' (Ö7)

'Öğrencilerimle zaman zaman eğlenebilmek adına oyuna katılırım.' (Ö3)

'Çocuklarla birlikte oyun oynamayı seviyorum. Onlarla beraber oynamak onlar için de keyifli oluyor. Oyun oynarken beni de oyun içinde görmek istiyorlar.' (Ö21)

\section{Günlük Programda Dış Mekân Oyunları İçin Ayrılan Zaman Dilimleri}

Araştırmada yer alan okullarda genel olarak dış mekân oyunları için özel olarak belirlenen bir zaman dilimi bulunmamaktadır. Araştırmaya katılan okullardan sadece 2 tanesinin kesin olarak belirlenmiş bir zaman dilimi var. Bu okullardan bir tanesinde 1 saatlik dış mekân için ayrılan belirli bir zaman dilimine sahip oldukları ve okul öncesi eğitim programındaki bütün sınıfların aynı anda bu zaman dilimini dış mekânda geçirdikleri belirtilmektedir. Diğer okul ise günlük eğitim programlarında 30-45 dk. olarak belirlenen zaman dilimini dış mekânda geçirmektedir.

Araştırmaya katılan diğer okulların $(n=4)$ dış mekân oyun zamanları öğretmenlerin günlük akış için hazırladıkları programa göre değişmekte ve belirli bir zaman dilimi bulunmamaktadır. Ayarlanan dış mekân oyun zamanı bazı zamanlarda 1015 dk’ya kadar düşmektedir. Öğretmenler günlük programlarında dış mekân için ayrılmış bir zaman dilimi olmamasının nedenleri olarak hava koşullarını, yeterli dış mekân alanlarının olmamasını ve okul programlarının yoğun olmasını belirtmişler.

'Hava koşularının yağışlı ve soğuk olması' (Ö11)

'Ders programının akışı ve yoğunluğu' (Ö15)

'Okul öncesi öğrenciler için uygun oyun alanları olmadığı için oyunlar oynatılmada zorluklarla karşılaşılabiliyor.' (Ö18)

Bunlara ek olarak dış mekân oyunları için belirlenen zaman dilimleri mevsimsel olarak farklılık göstermektedir $(n=21)$. Özellikle katılımcılar sıcak havadan ziyade soğuk hava koşullarının $(n=19)$ çok etkili olduğunu belirtmişlerdir. 
'Kışın hava çok çok soğuk, yerler buzlu ise süreyi azaltıyoruz. Ancak çok nadiren!' (Ö5)

'Genellikle saatler aynı tutulmasına karşın, çok yağış olduğunda ve buzlanma varsa dışarı çıkılmıyor.' (Ö6)

Bununla birlikte okul öncesi kurumlarda çocukların kıyafetlerinin farklı mevsimsel koşullar altında, dış mekân oyunları için uygun olmadığını ve aile tutumunu belirtmişlerdir. Bu koşullar çocukların sağlık koşullarını olumsuz etkileyeceği için dış mekân oyunları için ayrılan zaman dilimi yağışıı ve soğuk havalarda azalmaktadır.

' $\mathrm{Bu}$ yıl soğuk hava nedeniyle sadece öğleden sonra daha kısa süre ile dışarı çıktık. Ayrıca aileler çocuklarını her zaman kış mevsimine ve dışarıda oyun oynamaya uygun kıyafetlerle göndermiyorlar.' (Ö3)

'Hava şartlarında dolayı ailelerin açık hava etkinliklerine karşı tutumu.' (Ö19)

\section{Dış Mekân Oyunlarında Uygulanan Planlar ve Dış Mekâna Çıkartılan Materyaller}

Araştırmaya katılan 17 öğretmen diş mekân oyunları için ayrıca bir plan ya da aktivite hazırlarken, 13 öğretmen hazırlamadıklarını belirtmiştir. Plan ve aktivite hazırlayan öğretmenler genellikle işlenen konu ile ilgili uygulamaları, çevre eğitimi ya da geleneksel oyunları dış mekân planlarında uyguluyorlar. Dış mekân oyunları için belirlenmiş bir zaman dilimi olmayan öğretmenler daha çok planlı etkinlikler tercih ederken, belirli bir zaman dilimine sahip öğretmenler planlı aktivite tercih etmiyorlar.

Araştırmanın sonuçlarına göre öğretmenlerin büyük çoğunluğu $(n=25)$ diş mekân oyunları için sınıf içinden materyal ya da ekipman çıkartırken beş öğretmen çıkartmıyor. Dış mekâna çıkartılan materyaller genel olarak hocaların tercihine ya da aktivitelere göre şekilleniyor. Büyük kas gelişimi ile ilgili olarak daha çok çember, top, ip, balon ve bisiklet gibi materyaller çıkartılırken, küçük kas gelişimine katkısı olan oyun hamuru, mercekler, büyüteç, yapboz, satranç kâğıt ve kalem gibi materyaller çıkartılmaktadır. Dış mekâna artık materyal çıkarttığını belirten öğretmen olmamıştır.

'Dış mekân oyununu genellikle ünitelerimizle birlikte kullanmaya çalışıyoruz.'

'Spor Günü ve Gezi Günü gibi özel aktiviteler hazırlayarak onları dışarıda kutluyoruz.' (Ö17) 


\section{Ekipmanlar}

Dış Mekânda Çocukların Oynadıkları Oyun Türleri, Materyaller ve

Aşağıdaki tabloda dış mekân oyunları sırasında öğretmenlerin en çok gözlemledikleri oyunlar gösterilmektedir.

\section{Tablo 5}

Dış Mekânda Çocukların Oynadıkları Oyun Türleri:

\begin{tabular}{lll}
\hline \multicolumn{1}{c}{ Yapılandırılmış Oyunlar } & Yarı-Yapılandırılmış Oyunlar & \multicolumn{1}{c}{ Yapılandırılmamış Oyunlar } \\
\hline Futbol,Basketbol,Voleybol & Kovalamaca & Evcilik \\
Sek sek & Ebelemece & Kazı \\
Saklambaç & Yuvarlanma & Kardan adam yapma \\
Yerden Yüksek & Tirmanma & Kar topu \\
İstop & Bisiklete binme & Çamur ile oynama \\
Yakan Top & Hulahop & Kum havuzunda oynama \\
Mendil Kapmaca & Sallanma & \\
Kutu Kutu Pense & İ ile oynama & \\
Sicak-Soğuk & Parktaki ekipmanlarla oynama & \\
Minder Kapmaca & Halka oyunları & \\
Köşe Kapmaca & & \\
Körebe & & \\
\hline
\end{tabular}

Tablo 5'te listelenen oyun türlerinden, yapılandırılmış ve yarı yapılandırılmış oyunların dış mekân süresince oynanan oyunlar arasında daha çok belirtildiği görülmektedir. Ayrıca çocukların dış mekân oyunlarında tercih ettikleri açık uçlu materyaller genel olarak bloklar, çeşitli kaplar, doğal materyaller (taş, çamur, kum, yapraklar, toprak, kozalak, dal parçaları, vs.), mandallar, lego, çeşitli toplar gibi örneklendirilmiştir. Çocukların dış mekân oyunları sırasında kullandıkları yapılandırılmış materyaller ise park ekipmanları, scooter, bisiklet, paten, büyüteç gibi malzemelerdir. Öğretmenler $(n=30)$ çocukların diş mekânda park ekipmanları, top ve iple oynadıklarını belirtirken, doğal materyallerle oynadıklarını belirten 6 öğretmen vardır. $\mathrm{Bu}$ materyaller arasında sadece iki öğretmen çamur ile oynadıklarını ve bir öğretmen kozalak ve mandal ile oynadıklarını belirtmiştir.

\section{Okullarda Bulunan Dış Mekân Oyun Materyalleri ve Ekipmanları}

Araştırmaya katılan okullarda $(n=6)$ bulunan materyal ve ekipmanlar, salıncak, tırmanma aleti/ipi, toplar, kaydırak, ağaç/çalı, tahterevalli ve çember/hulalop. Öğretmenler tarafından verilen cevaplara göre en az bulunanlar ise kum havuzu $(n=2)$, boş karton ( $n=1)$, plastik kutular $(n=1)$, kürek/tırmık $(n=1)$, yerden yüksek ev $(n=1)$, su $(n=1)$, kulübe $(n=1)$ ve evcilik malzemeleri $(n=1)$ olarak belirlenmektedir.

\section{Sonuç ve Tartışma}

Bu çalışmanın sonuçlarına göre okul öncesi öğretmenleri dış mekân oyunlarına karşı olumlu düşüncelere sahiptir. Çocuklara daha çok geniş alan ve özgürlük tanıdığında, dış mekânda oyunun aynı zamanda sağlıklı olmalarına ve gelişimlerine 
katkıda bulunduğunu düşünüyorlar. Fiziksel, bilişsel ve sosyal-duygusal alanlarda gelişimlerine katkıda bulunduklarını belirtmişlerdir. Bu sonuçlar Chakravarthi'nin (2009) yaptığı çalışmayı destekleyen sonuçlara sahiptir. Benzer çalışmada okul öncesi öğretmenleri dış mekânları, çocukların fiziksel ve sosyal gelişimlerini destekleyici, doğayı öğrenmelerini sağlayabilecek yerler olarak gördükleri söylenebilir. Ayrıca Umman'da yapılan bir araştırmada öğretmenler dış mekân oyunlarını günlük eğitim akışının önemli bir parçası olarak gördüklerini ve çocukların gelişimleri ve sağlıkları için önemli olduğunu ifade etmişlerdir. Ancak dış mekân oyunlarına ayrılan zaman diliminin kısıtlı olduğunu belirtmişlerdir (Al-Qaryouti \& Ihmeideh, 2015).

Alanyazına bakıldığında, öğretmenler dış mekânda denetleyici, gerekli zamanlarda oyunları yönlendirici ve çocuklarla iletişim halinde oldukları bir role sahip olmaları gerektiğini düşünmektedirler (Chakravarthi, 2009). Dış mekân oyunları sırasında öğretmenler genellikle denetleyici rolü üstlenmekte ve dış mekânların fiziksel tasarımlarının, çocuklar için çevre koşulları planlama, hazırlama ve katkıda bulunma açısından kendilerini engellediklerini düşünmektedirler (Renick, 2009). Öğretmenler genel olarak çocukların oyunları sırasında gözetmen rolünü üstlenmekte ve öncelikle çocukların güvenliklerini sağlamayı amaçlamaktadırlar. Kendilerinin dış mekân oyunlarına katkıda bulunabileceklerinin farkında olmalarına rağmen alanla ilgili fiziki koşulların yetersizliğinin onlar için engel teşkil ettiğini düşünmektedirler (McClintic \& Petty, 2015). Bu çalışmanın öğretmen rolleri ile ilgili sonuçları da diğer çalışmalarla paralellik göstermektedir. Öğretmenler en çok ortam sağlayan, yol gösterici ve güvenliği sağlayan roller üstlenmektedir. Aynı şekilde öğretmenler çocuklara özgürlük tanımaları gerektiğine inandıkları için çocukların dış mekân oyunlarına kısmen katılmaktadır.

Öğretmenler genel olarak dış mekânları havalar iyi olduğu zaman dilimleri içerisinde kullanmaktadırlar (Mayrand \& Waters, 2007; Alat, Akgümüş \& Caval1, 2012). Aynı şekilde bu çalışmalar da öğretmenler çocukların hastalanmasından endişelendikleri için karlı ya da yağmurlu havalarda dış mekân oyunlarına yer vermemektedirler. Buna ek olarak öğretmenler çocukların uygun kıyafetlerinin okullarda bulunduramadıkları için soğuk havalarda dışarıya çıkamadıklarını söylemiştir. Diğer taraftan Bjørgen (2015) tarafindan Norveç’te Ekim 2012 ve Mart 2014 tarihleri arasında yapılan bir çalışmada çocukların dış mekân aktivitelerine katılım durumları, fiziksel aktiviteleri ve iyi oluşları incelenmiştir. Aktiviteler yerde kar olsa da yapılmakta hatta yapılan aktiviteler içinde kayak, yakalamacadan sonra en yüksek katılım durumu, iyi oluş ve fiziksel aktivite oranına sahip olduğu görülmüştür. Aynı zamanda, Amus’un belirttiğine göre (2012), doğal ortamlar Finlandiya'da eğitim için önemli bir element olarak görülüyor ve çocuklar hava yağmur, dolu ya da kar yağıyor olsa bile her gün dışarıya çıkıyorlar. Amus en çok 'Kötü hava diye bir şey yoktur, yanlış kıyafet vardır.' anlayışına alışmanın zor olduğunu ama her mevsimin farklı koşullarını ve doğa olaylarını gözlemleyebilme şansı buldukça bu duruma alıştığını belirtmiştir. Ayrıca açık hava okulları, Waldorf okulları, orman okulları ve Skogsmulle okullarının benzer prensipleri olduğundan bahsetmiştir. $\mathrm{Bu}$ bilgiler göz önünde bulundurulduğunda, aslında kötü olarak nitelendirilen hava koşullarının eğitim programları içerisinde dış mekân oyunlarına zaman ayırmaya bir engel olmadığı görülmektedir. Gerekli kıyafetler ve ekipmanlar sağlandığı takdirde çocuklar Türkiye'de de kış aylarında dış mekân oyunları oynayabilirler. $\mathrm{Bu}$ çalışmada da belirtildiği gibi ailelerin hava koşulları 
nedeniyle dış mekân oyunlarına yaklaşımları olumsuz olabilmektedir. Cevher-Kalburan (2014b), anket kullanarak 398 ebeveynin katılımıyla tamamladığı çalışmasında ebeveynlerin diş mekânda oyun ile ilgili görüşlerini belirlemiştir. Trafik ve kötü niyetli yabancıların yanı sıra fiziksel yaralanma, kirlilik ve hastalanma gibi ebeveyn kaygıları olduğu görülmektedir. Ebeveynler bu kaygılarının kötü hava koşulları nedeniyle gerçekleşebileceğini düşünmeleri sebebiyle dış mekân oyunlarına karşı oldukça etkileri bulunmaktadır. $\mathrm{Bu}$ nedenle, konu ile ilgili aile desteği sağlanabilmesi için öncelikle öğretmenler için eğitimler düzenlenmeli ve okul yöneticileri de bilinçlendirilmelidir. Dönem başında ebeveynlerle yapılacak toplantılarda öğretmenler okul yöneticisinin de desteği ile ebeveynleri kış aylarının dış mekân oyunları için engel olmadığı ve okul programında yer alacağı konusunda bilgi verebilirler.

Araştırmaya katılan altı kurumdan sadece iki tanesinde günlük akış içinde dış mekân oyunları için belirlenen zaman dilimi olduğu görülmüştür. Okullardan bir tanesinde bir saat, diğerinde 30-45 dk'llk zaman ayrılmaktadır. Hastalık Kontrol ve Önleme Merkezi'ne göre (Center for Disease Control and Prevention-CDCP, 2017) çocukların sağlıklı olabilmesi için günde en az bir saat fiziksel aktivite yapmaları gerekir. Sunduğu geniş alan, özgürlük ve farklı aktivitelerle dış mekân alanları bunun için ideal bir ortam sağlar ve öğretmenler eğitim programlarında dış mekân oyunlarına yer verebilir.

Ulusal Okul Öncesi Eğitim Programında oyun ve hareket eğitimi ile ilgili bilgi verilirken dış mekân etkinlikleri müfredatta ayrıca bir yere sahip değildir (MEB, 2013). Bu çalışmaya katılan öğretmenler de dış mekân için iç mekânda kullandıkları konularla bağlantılı ve çevre eğitimi ile ilgili kendilerinin yönetebilecekleri aktiviteler hazırladıklarını belirtmişlerdir. Aynı zamanda dış mekân oyunları için plan hazırlamayan öğretmenlerin, günlük eğitim akışlarında belirli zaman dilimine sahip olan öğretmenler olduğu görülmüştür. Alat, Akgümüş ve Cavalı (2012) tarafından yapılan araştırmaya göre aynı şekilde okul öncesi öğretmenlerinin açık hava etkinlikleri ile ilgili olumlu düşüncelere sahip olmalarına rağmen uygulama konusunda yetersiz kaldıkları görülmektedir. McClintic ve Petty (2015), okul öncesi öğretmenlerinin konu ile ilgili görüş ve uygulamalarını belirlemek için yaptıkları araştırmada öğretmenlerin dış mekân oyunlarının çocukların gelişimlerine olan önemini bildikleri ama uygulama konusunda yeterli bilgi ve motivasyona sahip olmadıkları bulgusuna ulaşmışlardır. Benzer şekilde bu araştırmada da öğretmenlerin dış mekân oyunlarının gerekli olduğunu ve desteklenmesi gerektiğini bilseler de dış mekânın etkili kullanılması konusunda yeterli bilgiye sahip olmadıkları görülmüştür. Diğer taraftan Al-Qaryouti ve Ihmeideh (2015), dış mekân oyunları için yetersiz açık alan olması, sıcak hava koşulları ve çocukların yaşlarına uygun ekipmanların olmaması önemli zorluklar olarak ortaya çıkmaktadır. Ancak bu araştırmadan farklı olarak, öğretmenlerin büyük bir kısmı güvenlik önlemlerinin yeterli olduğunu ama kendilerinin konuyla ilgili olarak daha fazla bilgiye sahip olmaları gerektiğini düşünmektedirler. Bu nedenle öğretmenlerin diş mekânla ilgili eğitim gereksinimleri üniversitedeki ders içerikleri, çalıştaylar ve seminerlerle desteklenmelidir.

Bulguların gösterdiğine göre öğretmenlerin çoğunluğu iç mekândan diş mekâna materyal çıkartmakta ancak çıkartılan materyaller genel olarak öğretmenlerin tercihine ve aktivitelere göre belirlenmekte, bu durum da yıldırıcı olmaktadır. Oysa Hyndman, Benson ve Telford (2014) yaptıkları araştırmada bir okulun oyun ekipmanları 
bulunmayan çim alanına süt kasaları, karton kutular, lastik tüpler ve tahta kalaslar gibi hareketli/geri dönüşebilen materyaller koyarak bir müdahale araştırmasının yedi hafta sonrasında, çocukların materyalleri kullanarak yapılar oluşturmaya başladıklarını ve yaratıcı oyunların görülme oranının \%5,6 dan \%52,8'e çıktığını göstermişlerdir.

Araştırmadaki sonuçlara göre öğretmenler çocukların dış mekânda genel olarak ip, top gibi materyaller ve park ekipmanları ile oynadıklarını belirtmiş̧lerdir. Çocukların dış mekânda doğal materyallerden çok yapılandırılmış park ekipmanları ve oyuncaklarla oynadıkları sonucu görülmektedir. Ancak öğretmenler aynı zamanda dış mekâna çıkma zamanlarının sınırlı olması konusunda kıyafet konusunu belirttikleri için bu durumun nedeni çocukların ebeveynlerinin ve öğretmen yönlendirmesi sebebiyle kirlenmekten çekinmeleri olabilir.

Dış mekânda bulunan ekipmanlar ve materyaller geleneksel oyun parklarında olan ekipmanlar ve top, ip çember gibi materyaller olurken sadece bir okulda diş mekânda su ve karton kutular olduğu belirtilmiştir. Türkiye'de yapılan benzer araştırmada okul öncesi kurumlarda doğa ile etkileşimi sağlayamayan günümüzde sıklıkla gördüğümüz geleneksel oyun parklarından olduğu tespit edilmiştir (Alat, Akgümüş \& Cavalı, 2012; Cevher-Kalburan, 2014). Benzer olarak dış mekânın tasarımı, bulunan materyal ve ekipmanların yetersizliği, güvenlik endişesi ve eğitim politikaları dış mekânda geçirilen zamanı sınırlayan nedenler arasında yer almaktadır (Mayrand \& Waters, 2007).

$\mathrm{Bu}$ çalışmanın araştırma yöntemi olarak açık uçlu sorulardan oluşan form uygulanmıştır. Tek bir veri toplama yöntemi olması ve bulgular öğretmenin cevaplarına bağlı olması nedeniyle araştırma sınırlanmıştır. Ayrıca araştırma katılımcıları sadece özel kurumlarda çalışan 30 okul öncesi öğretmeni ile sınırlı kalmıştır. Gözlem ve görüşme gibi başka araştırma yöntemleri kullanılarak ve araştırmanın alanı farklı bölgelere ya da devlet kurumları ile genişletilerek farklı sonuçlara ulaşılabilir. Ayrıca araştırmada okul öncesi öğretmenlerinin davranış ve tutumları incelenmiş̧tir. Buna ek olarak kurumların yöneticileri, müdürleri ve eğitim koordinatörlerinin dış mekân oyunları hakkındaki görüşleri alınabilir.

Araştırmanın sonuçlarına dayanarak, dış mekân oyunları çocukların gelişim alanları ve sağlıklı bir birey olmaları için önemlidir ve okul öncesi öğretmenleri dış mekân oyunlarına karşı olumlu görüşlere sahip olduğu gözlenmektedir. Ancak dış mekân oyun alanlarının tasarımlarının yetersizliği, öğretmenlerin dış mekânda oyunu planlama ve uygulamaya yönelik algıladıkları düşük öz-yeterlik, çocukların sağlıkları konusunda endişeler ile dış mekân oyunlarına gün içinde gerekli seviyede yer verilmediği gözükmektedir.

Millî Eğitim Bakanlığı'nın 2013 Okul Öncesi Eğitim Programı'nda dış mekânın kullanımıyla ilgili daha kapsamlı açıklamalar yer almalı ve öğretmenlere konu ile ilgili eğitim programları, seminerler ve atölye çalışmaları verilerek eğitim programının ve uygulamalarının kalitesinin artırılmasına yardımcı olacaktır. Yükseköğretim, okul öncesi öğretmenliği programında Oyun Öğretimi dersi yer almakta ancak dersin diş mekân oyunları ve oyun alanları ile ilgili içeriği farklılık göstermektedir. Yükseköğretim programlarındaki dersler içerisinde diş mekân uygulamalarına yer verilmesi öğretmen adaylarının konu ile ilgili farkındalı̆̆ 1 ve bilgi seviyesinin arttırılmasında destek olacaktır. Ayrıca ebeveyn eğitimi Milli Eğitim Bakanlığı, Sağlık 
Bakanlığı ve medya kurumlarının desteğiyle sağlanarak farklı hava koşullarında dış mekân oyunlarının gerekliliği ve doğal ortamların önemi anlatılabilir.

Dış mekân uygulamalarının yetersiz olması konusunda önemli bir faktör olan bir diğer konu ise dış mekân oyun alanlarının ekipman ve materyalleridir. Dış mekân tasarımlarına belirli standartlar getirilerek kurumların denetimleri yapılabilir. Ayrıca çocukların yağmurlu ve karlı havalarda dış mekân oyunlarına katılabilmeleri için materyal ve kıyafet konusunda kurumların düzenlemeler yapması dış mekânda geçirilen zaman dilimlerinin arttırılmasına katkı sağlayacaktır.

Son olarak öğretmenlerin davranış ve tutumlarının yanı sıra konuya çocukların bakış açısını da ele alan çalışmalar eklenerek alanında uzman kişilerin okul öncesi eğitim kurumlarının tasarımı, eğitim programlarının hazırlanması ve uygulanmasına yönelik etkinlikler ve kitapçıklar hazırlaması, dış mekân oyunlarına ilişkin tutum ve uygulamaların geliştirilmesine katkıda bulanacaktır. 


\section{Summary}

Purpose and Significance: Outdoors provide open spaces for children to move freely and offer them a chance to discover their environment (Burriss \& Burriss, 2011; Mayrand \& Waters, 2007). They can do such movements as running, climbing, or jumping (Rivkin, 2000). Such movements would ensure increase the amount of oxygen in their body, blood circulation and the amount of nutrition that reaches the tissues (Ünal, 2009). Due to its various benefits, outdoor play takes a little attention in educational arena (Ahern et al., 2011). Early childhood institutions play critical roles in supporting outdoor play. However, the majority of these institutions mostly offer indoor activities due to limited play spaces or equipment (Baran, Y1lmaz, \& Y1ldırım, 2007; Çelik, 2012). Besides, the attitudes and behaviors of educators also have effects on children's outdoor play opportunities (Johnson, Christie, \& Yawkey, 1998) and it is necessary to investigate their perspectives in depth. Therefore, the current study aims to investigate early childhood educators' attitudes, implementations, and experiences regarding outdoor play. Two research questions were investigated: (1) what are the attitudes of early childhood educators regarding outdoor play? (2) what are the implementations and experiences of early childhood educators regarding outdoor play?

Methods: An Open-ended questionnaire developed by the researchers was used to determine the perspectives of the participants. There were 13 questions for the participants. After obtaining ethical approvals and expert opinions, 30 early childhood educators from six private school were invited to participate to the study. The responses of the participants were analyzed and presented descriptively.

Results: The findings indicated that teachers have mostly positive attitudes towards outdoor play in early years. They think outdoor play as an important contributor to the child development and healthy growth. Regarding their role while being outside with children, the teachers usually become stage managers and directors. They also stated their concerns about weather conditions, especially during the winter times. Of the six institutions, only two of them had a specified time for outdoor play. One of them had an hour and the others had 40-45 minutes of outdoor play time per day. Besides, teachers indicated that they did not have any activity preparations while going outside. During outdoor play time, teachers indicated that children usually prefer to play with balls, ropes, and playground equipment. They also, according to their teachers, prefer to play with structured materials and manufactured toys instead of playing with more open and natural material. The majority of the outdoor play areas included traditional equipment and materials such as swings and slides and only one center had water and carton boxes in the outdoor play area.

Discussion and Conclusions: The study results indicated that the teachers have positive attitudes towards outdoor play. However, they have limited knowledge about the outdoor play activity implementations. Besides, the teachers indicated their concerns about the safety and their roles in becoming safety patrols during outdoor play time. As in the Chakravarthi's (2009) and Renick's, (2009) studies, teachers generally think that they should be a director or a play leader during the outdoor play time or mostly taking a role of a controller. Similar to other research results, the teachers in the current study indicated the weather conditions as a critical factor for deciding to go outside 
(Alat, Akgümüş, \& Cavalı, 2012; Mayrand \& Waters, 2007). However, Bjørgen (2015) pointed out that children who spend time outdoors have high physical activity levels and well-being, especially during winter times. Furthermore, open air schools, Waldorf schools, forest schools and Skogsmulle schools have similar principles with Norway educational program. In the light of these, when proper clothes and necessary equipment are provided, children should go outside in every weather condition.

As a result, it is necessary to offer children quality outdoor play time opportunities. To be able reach that purpose, schools need to reform their play areas in terms design, equipment and materials. It is also very necessary to prepare teachers to the dynamics of outdoor play and inform them about their role as a co-player, rather than being a safety guard. In addition to the attitudes of teachers, the viewpoints of the children would also be included while designing play areas specific to their interests. 


\section{Kaynakça}

Afsharlahoori, F. (2007, November). Study on outdoor playground equipment and children's social and physical development. Paper presented at 7th International Association of Societies of Design Research Conference. Hong Kong-China

Ahern, R., Beach, R., Leibke, S. M., Proud, I., Spencer, A., \& Stricland, E. (2011). The benefits of play go well beyond physical fitness. The Early Childhood Leaders' Magazine, 201, 68-70.

Ahiloğlu-Lindberg, N. (2012). Çocuk oyunlarında iki kuşakta görülen değişim. International Online Journal of Educational Sciences, 4(2), 395-410.

Alat, Z., Akgümüş, Ö, \& Cavalı, D. (2012). Okul öncesi eğitimde açık hava etkinliklerine yönelik öğretmen görüş ve uygulamaları. Mersin Üniversitesi Ĕgitim Fakültesi Dergisi, 8(3), 42-62.

Al-Mansour, M., Sevimli-Celik, S., \&. Johnson, J.E. (2016). Transcultural study of play: Turkish and Saudi Mothers' beliefs about play. Play \& Culture Studies, 13, 149-169.

Al-Qaryouti, I. A. \& Ihmeideh, F. M. (2015). Exploring kindergarten teachers' views and roles regarding children's outdoor play environments in Oman. Early Years, 36(1), 81-96.

Amus, G. (2012). An alternative journey into forest kindergartens and the Reggio Emilia approach. Reports and Studies in Education, Humanities, and Theology, 7(1), 5-26.

Anderson-McNamee, J. K. \& Bailey, S. J. (2010). The importance of play in early childhood development. Montana State University Extention, 1-4.

Atabey, D., Yurt. O., \& Omeroğlu, E. (2009, Eylül). Okul öncesi eğitim kurumları acık hava oyun alanlarının incelenmesi. Uluslararası 5. Balkan Eğitim ve Bilim Kongresi'nde sunuldu. Edirne-Türkiye

Baltac1, A. (2017). Nitel veri analizinde Miles-Huberman Modeli. Ahi Evran Üniversitesi Sosyal Bilimler Enstitüsü Dergisi, 3(1), 1-15.

Baran, M., Y1lmaz, A., \& Y1ldırım, M. (2007). Okul öncesi eğitimin önemi ve okul öncesi eğitim yapılandırmalarındaki kullanıcı gereksinimleri. Dicle Üniversitesi Ziya Gökalp Ĕ̈itim Fakültesi Dergisi, 8, 27-44.

Başal, H. A. (2007). Geçmiş yıllarda Türkiye'de çocuklar tarafindan oynanan çocuk oyunları. Uludă̆ Üniversitesi Ĕ̈itim Fakültesi Dergisi, 27, 243-266.

Bjørgen, K. (2015). Children's well-being and involvement in physically active outdoors play in a Norwegian kindergarten: Playful sharing of physical experiences. Child Care in Practice, 21(4), 305-323. http://dx.doi.org/10.1080/13575279.2015.1051512

Burris, K. \& Burris, L. (2011). Outdoor play and learning: Policy and practice International Journal of Education Policy and Leadership, 6(8), 1-12.

Center for Disease Control and Prevention (2015). How much physical activity do children need? https://www.cdc.gov/physicalactivity/basics/children/index.htm Erișim Tarihi: 08.03.2017 
Cevher-Kalburan, N. \& Yurt, Ö. (2011, July). School playgrounds as learning environments: Early childhood teachers' beliefs and practices. Presented at 7th International Conference on Education INEAG. Samos-Greece.

Cevher-Kalburan, N. (2014a). Denizli ilinde bulunan resmi ve özel anaokulu bahçelerinin karşılaştırmalı olarak incelenmesi. Pamukkale Üniversitesi Sosyal Bilimler Enstitüsü Dergisi, 18, 99-113

Cevher-Kalburan, N. (2014b). Okul öncesi dönem çocukların diş mekânda oyun firsatları ve ebeveyn görüşleri. Sosyal Politika Çalışmaları Dergisi, 32, 113-135.

Chakravarthi, Swetha. (2009). Preschool teachers' beliefs and practices of outdoor play and outdoor environments (Unpublished doctoral dissertation). University of North Carolina at Greensboro.

Clements, R. (2004). An investigation of the status of outdoor play. Contemporary Issues in Early Childhood, 5(1), 68-80.

Çelik, A. (2012). Okul öncesi eğitim kurumlarında açık alan kullanımı: Kocaeli örneği. Atatürk Üniversitesi Ziraat Fakültesi Dergisi, 43(1), 79-88.

Duman, G. \& Koçak, N. (2013). Çoçuk oyun alanlarının biçimsel özellikleri açısından değerlendirilmesi (Konya ili örneği). Türk Ĕgitim Bilimleri Dergisi, 11(1), 64-81.

Erbay, F. \& Saltalı, N. D. (2012). Altı yaş çocuklarının günlük yaşantılarında oyunun yeri ve annelerin oyun algısı. Ahi Evran Üniversitesi Kırşehir Eğitim Fakültesi Dergisi, 13(2), 249-264.

Girsburg, K. R. (2007). The importance of play in promoting healthy child development and maintaining strong parent-child bonds.American Academy of Pediatrics, 119(1), 182-191.

Haapala, E. A., Poikkeus, A., Tompuri, T., Kukkonen-Harjula, K., Leppanen, P. H., Lindi, V., \& Lakka, T. A. (2014). Associations of motor and cardiovascular performance with academic skills in children. Medicine \& Science in Sports \& Exercise, 46(5), 1016-1024.

Hyndman, B. P., Benson, A. C., \& Telford, A. (2014). A guide for educators to move beyond conventional school playgrounds: The RE-AIM evaluation of the luchtime enjoyment activity and play (LEAP) intervention. Australian Journal of Teacher Education, 39(1), 1-99. http://dx.doi.org/10.14221/ajte.2014v39n1.2

Johnson, J. E., Christie, J. F., \& Yawkey, T. D. (1998). Play and early childhood development (2nd ed.). Addison Wesley Longman.

Karataş, Z. (2015). Sosyal bilimlerde nitel araştırma yöntemleri. Manevi Temelli Sosyal Hizmet Araştırmaları Dergisi, 1(1), 62-80.

Koçyiğit, S., Kök, M., \& Tuğluk, M. N. (2007). Çocuğun gelişim sürecinde eğitsel bir etkinlik olarak oyun. Atatürk Üniversitesi Kazım Karabekir Ĕ̈itim Fakültesi Dergisi, 16, 324-342.

Marcon, R. A. (2002). Moving up the grades: Relationship between preschool model and later school success. Early Childhood and Research \& Practice, 4(1), 1-20.

Mayesky, M. (2009). Creative activities for young children (9th ed.). Delmar, Cengagae Learning.

Mayrand, T. \& Waters, J. (2007). Learning in the outdoor environment: A missed opportunity? Early Years, 27(3), 255-265. 
McClintic, S. \& Petty, K. (2015). Exploring early childhood teacher's beliefs and practices about preschool outdoor play: A qualitative study. Journal of Early Childhood Teacher Education, 36(1), 24-43.

MEB (2013). Okul öncesi eğitim program1. http://tegm.meb.gov.tr/dosya/

Olgan, R. \& Öztürk, D. K. (2011). An investigation in the playgrounds of public and private preschool in Ankara. Education and Science, 36(161), 85-97.

Ozdemir, A. \& Yilmaz, O. (2008). Assessment of outdoor school environments and physical activity in Ankara's primary schools. Journal of Environmental Psychology, 28(3), 287-300.

Pesce, C., Masci, I., Marchetti, R., Vazou, S., Saakslahti, A., \& Tomporowski, P. D. (2016). Deliberate play and preparation jointly benefit motor and cognitive development: Mediated and moderated effects. Frontiers in Psychology, 7, 1-17.

Renick, S. (2009). Exploring Early Childhood Teachers' Beliefs and Practices about Preschool Outdoor Play: A Case Study (Unpublished Doctoral Dissertation). Texas Women's University at Denton.

Rivkin, M. S. (2000). Outdoor experiences for young children (ERIC Digest), Charleston, WV: ERIC Clearinghouse on Rural Education and Small Schools. ERIC Document Reproduction Service No. ED448013

Sarama, J. \& Clements, D. H. (2009). Building blocks and cognitive building blocks: Playing to know the world mathematically. American Journal of Play, 1(3), 313337.

Singer, D. G., Singer, J. L., D'Agnostino, H., \& DeLong, R. (2009). Children's pastimes and play in sixteen nations: Is free-play declining? American Journal of Play, 1(3), 283-312.

Tepebağ, D. \& Aktaş-Arnas, Y. (2017). Okul Öncesi öğretmenlerinin okul bahçesini eğitsel amaçlı kullanımına yönelik görüşlerinin incelenmesi. Uluslararası Erken Çocukluk Ë̆itimi Çalışmaları Dergisi, 2(2), 50-67.

Toksoy, A. C. (2010). Yarışma niteliği taşıyan geleneksel çocuk oyunları. Çevrimiçi Tematik Türkoloji Dergisi, 205-220. http://www.acarindex.com/dosyalar/makale/acarindex-1423866462.pdf Erişim Tarihi: 01.04.2017

Tuğrul, B., Ertürk, H. G., Özen Altınkaynak, Ş., \& Güneş, G. (2014). Oyunun üç kuşaktaki değişimi. The Journal of Academic Social Science Studies, 27, 1-16.

Tuğrul, B., Metin Aslan, Ö., Ertürk, G., \& Özen Altınkaynak, Ş. (2014). Anaokuluna devam eden altı yaşındaki çocuklar ile okul öncesi öğretmenlerinin oyun hakkındaki görüşlerinin incelenmesi. İnönü Üniversitesi Ĕ̌gitim Fakültesi Dergisi, 15(1), 97-116. doi: 10.17679/iuefd.05509

Ünal, M. (2009). The place and importance of playgrounds in child development. Inonu University the Faculty of Education, 10, 95-109.

Weisberg, D. S., Zosh, J. M., Hirsh-Pasek, K., \& Golinkoff, R. M. (2013). Talking it up: Play, language development, and the role of adult support. American Academy of Play, 6(1), 39-53. 
Yıldırım, A. \& Şimşek, H. (2011). Sosyal bilimlerde nitel araştırma yöntemleri. Ankara: Seçkin.

Zych, I., Ortega-Ruiz, R., \& Sibaja, S. (2016). Children's play and affective development: Affect, school adjustment and learning in preschoolers. Journal for the Study of Education and Development, 39(2), 380-400. 